\title{
微小重力での結晶成長
}

\author{
塚 本 勝 男 ${ }^{*}$
}

\section{Crystal Growth in Microgravity}

\section{Katsuo TsUKAMOTO*}

\begin{abstract}
Microgravity has been utilized not only for verifying the theories on diffusion of molecules in the liquid but for understanding the phenomena which are damped by gravity on earth and thus are invisible or not measurable, such as diffusion controlled growth, surface tension dirven convection (Marangoni convection) or pure homogeneous nucleation. These phenomena have a lot of influences on the growth of crystals. Some microgravity experiments were already started by the present author.
\end{abstract}

スペースシャトル，エンデバーが地球を周回している 間に，宇宙飛行士達は数多くの微小重力実験をこなして 無事帰還した。行われた研究テーマは10数年前に公募さ れたテーマであるが，マスコミで公表された実験以外に も多くの研究がなされた。このような宇宙実験は鉱物学 とは決して無縁ではなく，むしろ密接に結びついている ものである。

一例をあげよう。結晶の成因を議論する場合, 熱伝導 度や拡散係数は無視できない。一般に科学便覧や理科年. 表でもって, 温度依存性と共にその値を調べるわけであ る。では，その值はどの程度信頼できるものであろう か. もっとも良く調べられている半導体メルトの熱伝導 度をとっても，異なる実験者のデータは300\%も分散す る. その測定值は対流によって乱されるからである．本 来, 拡散現象は対流とは無関係に定義できよう。しか し, 重力場での測定では測定装置内の温度や濃度の勾配 により普遍的に対流が生じる. 対流での熱や物質の移動 速度は拡散に比べてはるかに速いことは明白である。し たがって，地上での測定では真の拡散現象に比べて大き な値が得られる.

拡散や熱伝導現象には未だにはっきりした理論的な裏 付けがないことも, 宇宙実験を行おうとする大きな動機 である.これまでの拡散速度の測定結果はアレニウスの 式で整理されていた。しかし，アレニウスの式はあくま で実験結果の整理につかうべきであって, 物理的な意味

* 東北大学理学部地球物質科学科

Institute of Mineralogy, Petrology and Economic Geology, Faculty of Science, Tohoku University, Aramaki Aoba, Sendai 980, Japan
を余り持たない事に注意を払う必要がある. 多数の研究 がなされている金属液体中での搪散現象を例にとってみ よう ${ }^{1,2)}$. 一般には拡散速度は次式で現されている。

$$
\mathrm{D}=\mathrm{D}_{\mathrm{o}} \exp (-\mathrm{U} / \mathrm{kT})
$$

ここで U, k, Tは, それぞれ, 活性化エネルギー, ボル ツマン定数, 絶対温度である. 問題はこの式には理論的 な根拠がないことである。拡散理論に立ち帰ってみよ う. Swalinは1950年代から拡散の理論式をいくつか導い ている。その一つに，第( 2 )式がある.

$$
\mathrm{D}=\mathrm{K} \cdot \mathrm{T}^{2}
$$

狭い温度範囲では実験の誤差範囲で( 1 )式と余り差はな い. しかし, 公い温度範囲, 特に粘性の小さくなる高温 領域での実験結果が得られなかった訳で, 実験的な検証 はなされなかったといえよう。したがって，余り深い考 慮無しに拡散係数の温度依存性はアレニウスの式(1)に従 うと考えられていた。

ところが，この事情は宇宙実験が行われるようになっ てから変わってきた。これまで拡散の実験はスペース シャトルでいくつかなされてきた。これらの全てのデー 夕は, 拡散係数は絶対温度の自乗に比例するという驚く べき結果を導いた．熱伝導にしても微小重力実験によっ て新たなデータが得られ始めている.このような地.で のデータと微小重力下での拡散や熱伝導の違いは, 地質 現象のような時間スケールでは大きな意味をもってくる と思われる。

このような重力の影響を除いた環境下での物理パラ メータを測定し，これまでの理論との対比によって基礎 


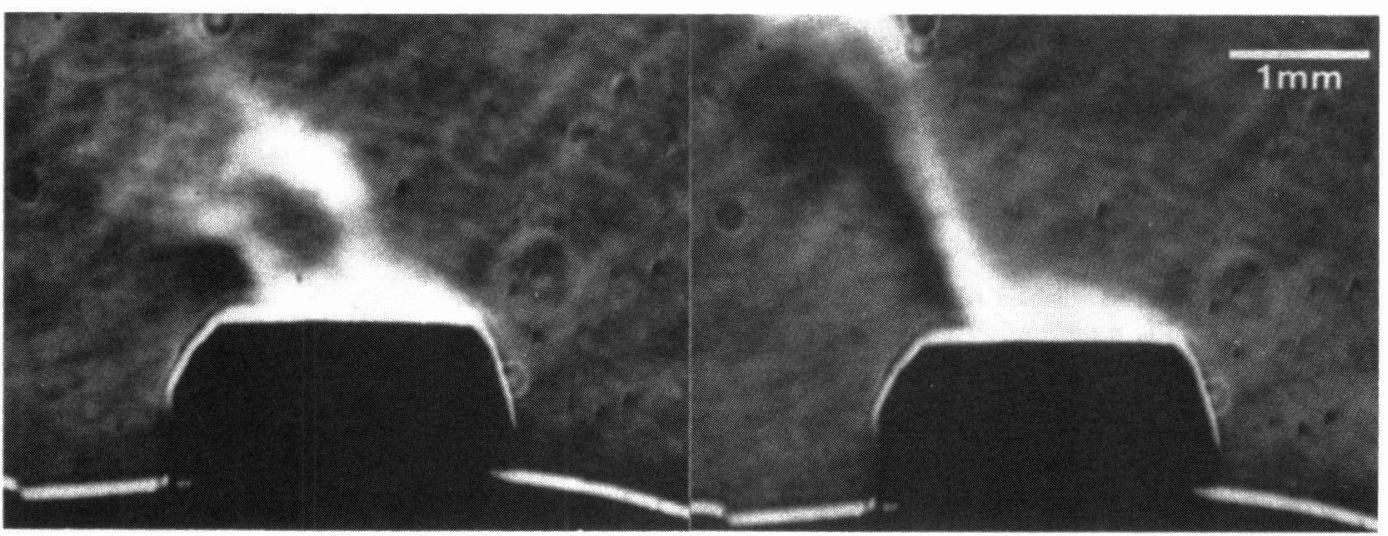

Fig. 1 Successive Schlieren images of unstable solutal convection, which is driven by the concentration gradient around a growing $\mathrm{Ba}\left(\mathrm{NO}_{3}\right)$, crystal $^{4}$.

現象の研究を行おうとする実験以外にも，多数の分野て 宇宙実験が行われようとしている。鉱物に密に関連する 結晶成長の分野もそのひとつである。もともと地上での 実験では多数の現象が重力によって㩊されている。たと えば，重力による対流のために拡散が覆い隐され，拡散 だけに支配される結晶成長はありえない。また，自由界 面が存在するときに生じる，表面張力差による対流(マラ ンゴニー対流)の結晶成長への影響は，対流によって調べ 難い。著者らが行ったこれらの実験の詳細は近日中に報 告する3)として，対流に起因するGROWTH ZONINIGに ついて考えてみよう。造岩鉱物に普遍的に見られる ZONINGの解釈はいくつかなされている。しかし，この 主な原因は成長している結晶近傍での流体挙動の不安定 性によるものと著者らは考えている。つまり，結晶が成 長するとともに結晶周井の組成は滅少する。そのために 成長している結晶近傍の溶液に浮力が生じ，対流が生じ るわけである。ここで重要なのは，成長する環境条件に よって対流の安定性が決まることである。例えば，水溶 液から硝酸バリウム結晶が成長している姿を濃度勾配に 非常に敏感なシュリーレン法で眺めてみると, 溶液の過 飽和度(よって，成長速度)が中間の領域でのみ，対流の 不安定性がおきることがわかる゙)(Fig.1)，ささらに高い過 飽和度では，かえって対流が安定する。興味あること

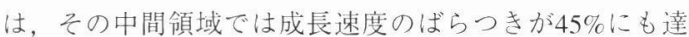
することである。結晶が成哀する溶液全体の温度は1/100 ○の安定性で制御されているのは勿論のことである。成 長速度が変動すれば元素の分配も変動するので, 成長么 ラによるZONINGが現れる。しかしここような原因以 外にも，結晶成長に伴う溶質と溶媒あるいは熱との相互。
拡散によってもゆらぎが生じる。しかし，重力下では上 記の対流が激しすぎて相互拡散によるゆらぎは実験的に はとらえられない. GROWTH ZONINGの出来かたは, 鉱物の成因とも結びつく重要な事柄であるにもかかわら ず，理論的にも実験的にも研究が進展しないのは，地上 ではこのような対流の影響が強すぎるからである。これ らの実験を対流を完全に抑制できる微小重力下で行おう とする計画はすでに進められている。

このような目的意識をもって, 著者らは, 昨年 9 月 16 日にロケットを用いた微小重力下での結晶成長のその場 観察实験老最初に行った5,6,7)。また，本年度より，北海 道上砂川の落下施設を用いた 10 秒間の微小重力実験も始 めている。さらに，今世紀末に運用開始される宁宙基地 での研究の準備は現在急ピッチで進んでいる，したがっ て, 微小重力を用いた研究は物質科学分野でも, 今後, 爆発的に増えるであろう。特に無重力下での結晶の核形 成は，地上での経験だけをもとにしては考えることが出 来ないであろう。

\section{参考文献}

1) 下地光雄(1988)：拡散の理論と宇宙実験. 日本結晶成長学 会誌，15，P.158.

2) 下地光雄(1989)：液体金属中の拡散と宇宙実験一Swalinの 理論との関連について。日本マイクログラビティ応用学 会誌，16，P.15.

3) 塚本勝男，日本鉱物学会誌，投稿予定

4) K. Onuma, K. Tsukamoto and I. Sunagawa (1988): Role of buoyancy driven convection in aqueous solution growth, J. Crystal Growth, 89, p.177.

5) 塚本勝男(1992)：TR-1Aロケット微小重力実験－1号機実 験成果報告，宇宙開発事業団編。

6) 塚本勝男, 日本マイクログラビティ学会誌，投稿中

7) 塚本勝男, 日本物理学会誌, 投稿予定 